Aina Aune Kane

aina.a.kane@uit.no

Sissel Neverdal

sissel.neverdal@uit.no

Vitenskapelig publikasjon

\title{
Sammendrag:
}

I forbindelse med revidering av lov om barneverntjenester har det regjeringsoppnevnte Barnevernslovutvalget foreslått å avgrense barneverntjenestens forebyggingsansvar til å spesifikt omfatte de barn som er «i risiko», og som har «særlig behov» for bistand. Alle barn har imidlertid et menneskerettslig krav på trygge oppvekstvilkår. Barneverntjenesten har en særlig kompetanse og erfaring med barn i risiko og bør derfor ta del i samfunnets kollektive ansvar for barn. Hensikten er å sikre nødvendig kompetanseutveksling med andre instanser som arbeider med og for barn. Slik kompetanseutveksling kan igjen sikre kortreist handlekraft innenfor lokalsamfunnene, motvirke individualisering av oppvekstproblematikk i lokalsamfunnene og sikre at barns egne perspektiver får nødvendig fokus i det universelle forebyggingsarbeidet.

Nøkkelord: barnevern, barnevernreformen, universell forebygging, lokalsamfunn, kompetanse, barns menneskerettigheter

\begin{abstract}
:
In connection with the current revision of the Child Protection Act, the appointed committee has proposed to delineate the Child Protection Services' prevention responsibility to specifically address children at risk and in need of assistance. However, all children have fundamental human rights regarding a safe upbringing. The Child Protection Services have particular expertise and experience with children at risk. Their participation, in the collective responsibility for children in general can thus ensure the necessary exchange of expertise with other bodies working with and for children. Such shared competence can promote timely and targeted actions within communities, counteract individualization of childhood problems, and also ensure that children's perspectives are given the necessary focus in the universal prevention work.
\end{abstract}

Key words: child protection, preventative work, competence, local communities, children's human rights 


\section{Barnevern - et vern med eller uten et universelt forebyggingsansvar?}

\section{Innledning}

I forbindelse med pågående revidering av lov om barneverntjenester 17. juli 1992 nr. 100 (barnevernloven, bvl.), har Barnevernslovutvalget foreslått å «[i]nnskrenke barnevernstjenestens ansvarsområde ved å ta bort barnevernstjenestens plikt til å delta i forebyggende innsats rettet mot alle barn og unge i kommunen»(NOU 2016: 16, s. 82). Endringsforslaget begrunnes med at barneverntjenesten bør prioritere sine ressurser til beskyttelse mot omsorgssvikt og overgrep for «barn som trenger det» (ibid, s. 92).

Barn utgjør 21 prosent av landets befolkning (SSB 2017A), og ifølge en undersøkelse utført av Children's Worlds har de fleste barn i Norge det jevnt over bra (Rees og Main 2015).

Likevel viser statistikk at et ikke ubetydelig antall barn og unge opplever ulike utfordringer og risikoer, som også påvirker dem inn i voksenlivet. Gjennom media har vi fått kjennskap til enkeltsaker om barn, hvor flere instanser har vært involvert, og hvor sakene har fătt alvorlig utgang for barn, for eksempel alvorlig skade, dødsfall og drap med påfølgende fengselsstraff (NRK 2018, Setten 2018, Storø 2017, Gulliksen 2010). Disse og lignende alvorlige saker har ført til at det regjeringsoppnevnte Barnevoldsutvalget har utredet hvorvidt og hvordan særlig alvorlige saker om overgrep og omsorgssvikt mot barn kunne blitt forebygget eller avdekket av tjenesteapparatet på et tidligere tidspunkt (NOU 2017: 12).

FNs konvensjon om barnets rettigheter av 20. november 1989 (barnekonvensjonen, BK) fremstiller barnets særlige menneskerettigheter og myndighetenes ansvar for sikring av disse. Det er derfor interessant å undersøke hvordan lovendringen kan føre til en styrking eller svekking av barnets rettigheter, ut fra problemstillingen: Hvilken betydning kan barneverntjenestens universelle forebyggingsansvar ha for sikring av barns rett til trygge oppvektvilkår?

For å få svar på problemstillingen vil vi innledningsvis redegjøre for hvordan barnets menneskerettslige krav på trygge oppvekstsvilkår fremgår av ulike bestemmelser i FNs barnekonvensjon, og vi vil her særlig fokusere på retten til en trygg oppvekst og utvikling, tilstrekkelig levestandard, beskyttelse mot omsorgssvikt og til å bli hørt i saker som angår dem. Deretter redegjøres det for kommunal barneverntjenestes lovpålagte 
forebyggingsansvar, slik det fremstår i gjeldende lovgivning, og slik det nå foreslås endret. Vi vil fortolke konvensjons- og lovbestemmelser for å stadfeste disses formål, innhold og avgrensninger. Bestemmelsene vil videre bli tolket i lys av øvrige rettskilder, herunder FNs barnekomités generelle kommentarer, lovforarbeider og juridisk litteratur. Som ledd i sitt overvåkningsansvar (BK art. 43(1)) utgir FNs barnekomité generelle kommentarer som synliggjør dens fortolkning av barnekonvensjonens ulike artikler eller temaer (Bendiksen og Haugli 2018). Skoghøy (2016, s. 6-7) fremhever at selv om ikke disse generelle kommentarer er formelt bindende for konvensjonsstatene, må tolkninger fra FNs barnekomité, som «det primære internasjonale håndhevingsorgan for barnekonvensjonen», tillegges «betydelig vekt som rettskilder». I tillegg vil vi anvende faglitteratur for å belyse forhold som påvirker barns oppvekstvilkår.

På dette grunnlaget vil vi drøfte hvilken rolle den kommunale barneverntjenesten bør ha i samfunnets kollektive ansvar for sikre rettighetene til de barn og barnegrupper som trenger mer enn hva som sikres på normalarenaer som eksempelvis barnehager og skoler. Våre drøftinger omhandler barneverntjenestens bidrag gjennom universell forebygging rettet mot barnets rett til trygg oppvekst og utvikling, beskyttelse mot overgrep og omsorgssvikt og å bli hørt i forhold som angår det. I tillegg drøfter vi hvordan barneverntjenestens deltakelse i kommunens samlede forebyggingsinnsats kan bidra til å sikre mer målrettet forebygging hos alle instanser som arbeider med og for barn.

\section{Myndighetenes ansvar for å sikre barns grunnleggende menneskerettigheter}

Myndighetene skal «respektere og sikre menneskerettighetene slik de er nedfelt i denne grunnlov og i for Norge bindende traktater om menneskerettigheter» (Kongeriket Norges grunnlov 17. mai 1815 (Grunnloven) § 92). Stang og Sveaass (2016, s. 22) omtaler menneskerettigheter som «grunnleggende rettigheter og friheter som er nødvendig for å leve et verdig liv i et demokratisk samfunn», og Bendiksen og Haugli (2018, s. 41) fremhever at barnekonvensjonen er «det første folkerettslig bindende instrument som spesifikt fastslår at barn har menneskerettigheter, ikke bare interesser og behov». Barnekonvensjonen er inkorporert i norsk lovgivning gjennom lov om styrking av menneskerettighetenes stilling i norsk rett 21. mai 1999 nr. 30 § 2 (4) og gjelder derfor som norsk lov. Gjennom Grunnloven $\S$ 
104 er myndighetene pålagt å tilrettelegge for barnets utvikling, blant annet ved å sikre barnets $\emptyset$ konomiske, sosiale og helsemessige trygghet. Grunnlovsbestemmelsen forankrer også barnekonvensjonens art. $3 \mathrm{om}$ at barnets beste skal være et grunnleggende hensyn ved handlinger og avgjørelser som angår barn. FNs Barnekomité uttrykker i sin generelle kommentar nr. 14 (2013) at dette gjelder handlinger og avgjørelser i både offentlig og privat sfære, både rettslige og administrative, og både handlinger og unnlatelser av å handle. Komiteen fremhever at «[å] se det beste for barnet som 'grunnleggende' krever en bevissthet om området barnas interesser må innta ved alle handlinger og en vilje til å prioritere disse interessene i alle forhold» (2013, s. 10).

Myndighetene skal sikre alle barn deres rettigheter etter konvensjonen, uavhengig av forhold som eksempelvis barnets eller foreldrenes hudfarge, kjønn, religion, etnisitet eller funksjonshemming (BK art. 2). FNs barnekomité beskriver i sin generelle kommentar nr. 7 (2005, s. 4) hvordan «[s]må barn som lider under flere former for diskriminering (f.eks. på grunnlag av etnisk tilhørighet, sosial og kulturell stilling, kjønn og/eller nedsatt funksjonsevne) er særlig utsatt». At alle er like for loven og ikke må utsettes for usaklig forskjellsbehandling, fremgår også av Grunnloven § 98. Sandberg (2014, s. 74) presiserer at myndighetenes plikt til å sikre en reell likhet overfor noen barn eller barnegrupper kan fordre positive tiltak for å «kompensere for en faktisk ulikhet».

Barnet har krav på trygg oppvekst og utvikling, noe som følger implisitt av barnekonvensjonens art. 3 (2) om sikring av nødvendig beskyttelse og omsorg som er nødvendig for barnets trivsel, og art. 6 om sikring av barnets rett til å overleve, vokse opp og utvikle seg. FNs barnekomité beskriver i sin generelle kommentar nr. 5 (2003, s. 4) at barnets rett til utvikling skal tolkes som et «holistisk begrep, som omfatter barnets fysiske, psykiske, åndelige, moralske, psykologiske og sosiale utvikling». Barnet har videre rett til vern av sitt privat- og familieliv (BK art. 8 og 16, jfr. art. 19 (2)), og dets rett til å vokse opp i sin familie skal sikres gjennom myndighetenes ansvar for å gi nødvendig bistand til foreldre for å støtte opp under deres omsorgsansvar. Bendiksen og Haugli (2018, s. 45) beskriver at blant annet «retten til deltakelse, omsorg, beskyttelse mot vold og overgrep, helse, utdanning, lek og fritid» er viktige områder for barnets rett til utvikling. Barnet har krav på en levestandard som er tilstrekkelig for dets behov og utvikling, og myndighetene har ansvar for å «treffe egnede tiltak for å hjelpe foreldre og andre som har ansvaret for barnet til å virkeliggjøre denne rettighet» gjennom materiell hjelp og støttetiltak (BK art. 27). Oppedal (2008) fremhever 
hvordan barnets behov kan komme i press dersom foreldre mottar økonomisk sosialhjelp som er tilmålt å kun dekke familiens basisbehov, og ikke barnets øvrige behov, for eksempel fritidsaktiviteter. Videre fremholder art. 3 (1) at barnets beste skal være et grunnleggende hensyn ved alle handlinger og avgjørelser som angår barnet. Barnets beste som prinsipp har som sentral funksjon å «promotere», altså fremme, «barns grunnleggende rettigheter i møte med voksnes rettigheter» (Sigurdsen 2015, s. 342).

Barnet har videre rett til beskyttelse mot overgrep og omsorgssvikt (BK art. 19), og FNs barnekomité presiserer i sin generelle kommentar nr. 13 (2011) at dette omfatter alle former for fysisk og/eller psykisk vold og ulike former for vanskjøtsel, herunder unnlatelse av å ivareta barns behov for trygghet i dagliglivet. I artikkelens 2. ledd fremgår det at beskyttelsestiltak bør omfatte «utforming av sosiale programmer som yter nødvendig støtte til barnet, og til dem som har omsorgen for barnet, samt andre former for forebygging [...]». Hennum (2016) påpeker at selv om norsk lovgivning gir barn god beskyttelse, bør den styrkes på områder som skal gi barn bedre beskyttelse mot seksuelle overgrep og omsorgssvikt. I tillegg fremhever forfatteren behovet for bedre beskyttelse av barn som vokser opp hos foreldre som er psykisk syke eller bruker rus.

Barnet har rett til å bli hørt i saker som gjelder det, og myndighetene skal tilrettelegge for at barnet særlig skal høres i administrativ saksbehandling som angår det (BK art. 12). FNs Barnekomité fremhever i sin generelle kommentar nr. 12 betydningen av å også høre barn som en gruppe, for eksempel der gruppen utgjør en skoleklasse eller i et bestemt lokalsamfunn. Videre fremheves det hvordan barns synspunkter kan «tilføre relevante perspektiver og relevant erfaring, og bør tas med i vurderinger når beslutninger skal treffes, politiske programmer skal utformes» (2009, pkt. 9). Sandberg (2016) fremhever utfordringer knyttet til å skape arenaer hvor barn kan uttrykke sin mening, og setter det i sammenheng med behov for $\emptyset \mathrm{kt}$ kompetanse i å snakke med barn og å ta deres ytringer på alvor.

Myndighetenes ansvar for sikring av barnets rettigheter er i Norge spredt på ulike instanser med ulike ansvarsområder, herunder helse- og omsorgstjenester, barnehager, skoler, Nav og barneverntjeneste. FNs Barnekomité uttaler i sin generelle kommentar nr. 13 (2011, s. 20) at risikofaktorer hos barn, som gruppe og som individer, må gjenkjennes primært av de som «kommer i kontakt med barn», og at disse må ha nødvendig kunnskap for å kunne gjenkjenne tegn på overgrep og omsorgssvikt. Myndighetenes ansvar innebærer altså å sikre at barn sees, slik at eventuelle bekymringer for overgrep eller omsorgssvikt blir identifisert og adressert av de ansvarlige, kompetente myndigheter på lovmessig og forsvarlig måte (Kane 2016). Dette 
fordrer at personale som arbeider med og for barn, har tilstrekkelig handlingsrom til å kunne identifisere og adressere bekymringer for et barn, og at de har kompetanse å gripe sitt handlingsrom på en måte som ivaretar barnets beste. I ansvaret for å sikre barns grunnleggende rettigheter ligger derfor også ansvaret for å motvirke at disse rettighetene blir svekket eller brutt.

\section{Barneverntjenestens forebyggingsansvar og den foreslåtte lovendring}

Etter dagens lovgivning pålegger barnevernloven § 3-1 kommunen å «ølge nøye med i de forhold barn lever under, og har ansvar for å finne tiltak som kan forebygge omsorgssvikt og adferdsproblemer». Videre fremgår det at barneverntjenesten har «spesielt ansvar for å søke avdekket omsorgssvikt, adferds-, sosiale og emosjonelle problemer så tidlig at varige problemer kan unngås, og sette inn tiltak i forhold til dette». I barnevernlovens forarbeider Ot.prp. nr. 44 (1991-92) (Barne- og familiedepartementet 1992, s. 106) uttales det at barnevernlovens forebyggingsbestemmelse «må ses i sammenheng med lovens formålsparagraf», som i lovens $\S 1-1$ beskrives som å sikre nødvendig hjelp til rett tid til barn i risiko, og å bidra til trygge oppvekstvilkår. Forebyggingsansvaret etter gjeldende lovgivning omfatter dermed både det enkelte barn og hele barnebefolkningen i angjeldende kommune.

Barnevernslovutvalgets lovendringsforslag innebærer å innskrenke barneverntjenestens «plikt til å delta i forebyggende innsats rettet mot alle barn og unge i kommunen» (NOU 2016: 16, s. 82). I utredningen bruker utvalget begrepene universell, selektiv og indisert forebygging (ibid, s. 87). Utvalget omtaler universell forebygging som «innsats rettet mot hele befolkningsgrupper (for eksempel alle barn og unge) uten at en har identifisert individer eller grupper med forhøyet risiko» (2016, s. 87-88). Selektiv forebygging beskrives av utvalget som «tiltak rettet mot grupper med kjent og/eller forhøyet risiko for å utvikle problemer», mens «tiltak rettet mot individer med høy risiko eller klare tegn på problemer» omtales som indisert forebygging (ibid, s. 88). Kommunens generelle ansvar for å engasjere seg i barns oppvekstvilkår for å forebygge omsorgssvikt og atferdsproblemer faller således innenfor universell forebygging, mens barneverntjenestens hjelpe- og omsorgstiltak for å unngå at barn får varige problemer av omsorgssvikt og atferdsproblemer, utgjør selektiv forebygging. Barneverntjenestens innsats i form av eksempelvis ettervern etter omsorgs- og atferdstiltak for 
å forhindre eller lette konsekvenser av ulike former for oppvekstproblematikk vil da falle inn under indisert forebygging.

Barnevernslovutvalget begrunner lovforslaget med at den tosidige målsettingen om at instansen skal ha ansvar både for universell forebygging og for selektiv og indisert forebygging, medfører utfordringer for barneverntjenestens ressursprioriteringer. Utvalget problematiserer også hvordan uklar ansvarsfordeling for barn med ulike utfordringer og problemer medfører at barneverntjenesten bruker ressurser på saker som faller inn under andre instansers ansvarsområder. Videre fremgår det at barneverntjenesten, med sin spesialkompetanse sammenlignet med andre tjenester, bør konsentrere seg om sin «kjerneoppgave»: beskyttelse mot omsorgssvikt og overgrep for «barn som trenger det» (ibid, s. 91-92), altså selektiv forebygging.

Samtidig som barneverntjenestens forebyggingsansvar foreslås innskrenket, foreslås en videreføring av «kommunens ansvar for å legge til rette for trygt oppvekstmiljø for alle barn i kommunen» og en innføring av plikt for kommunen å «ha plan for kommunens forebyggende arbeid rettet mot alle barn og unge». Utvalget foreslår også å «[i]nnføre en plikt for kommunen til å sørge for at kommunens tjenestetilbud rettet mot alle barn og familier er samordnet. Kommunen skal også når det er nødvendig samordne det kommunale tjenestetilbudet rettet mot et bestemt barn» (NOU 2016: 16, s. 82).

Barneverntjenesten plikter å «medvirke til at barns interesser ivaretas også av andre offentlige organer», samtidig som at de skal samarbeide med andre organer når slikt samarbeid kan bidra til å løse oppgaver regulert i barnevernloven (barnevernloven § 3-2).

Barnevernlovsutvalget foreslår å videreføre denne medvirknings- og samarbeidsplikten (NOU 2016: 16, s. 82), dog med det forbehold at barneverntjenestens samarbeidsplikt med tanke på barn som gruppe skal bortfalle. Videre uttaler utvalget at barnevernet må være en del av et helhetlig kommunalt tjenestetilbud, og at kommunen «skal vurdere hvordan barneverntjenestens særlige kompetanse kan integreres i kommunens universelle forebygging», fordi barnverntjenesten har viktig kunnskap om barn og unge som «bør utnyttes gjennom tverretatlige og tverrfaglige tilbud» og integreres i kommunens universelle forebygging (ibid, s. 92-93). 


\section{Barneverntjenestens betydning for sikring av barns menneskerettigheter gjennom forebygging}

\section{Barns rett til trygg oppvekst og utvikling fordrer $\varnothing \mathrm{kt}$ forebyggingsinnsats}

Barnevernslovutvalget begrunner sitt lovendringsforslag med at barneverntjenestens brede samfunnsoppdrag kan gå på bekostning av det å kunne gi forsvarlig bistand til rett tid til de barn og unge som lever under bekymringsverdige forhold. Myndighetenes ansvar for sikring av barns krav på en trygg oppvekst og utvikling innebærer å forebygge forhold som kan føre til blant annet omsorgssvikt, overgrep og atferdsvansker. De nordiske velferdsstatenes fremvekst bygger på en rekke sosialpolitiske tiltak som skal fremme gode oppvekst- og utviklingskår for barn, eksempelvis barnehage, skole, skolefritidsordning og helsestasjon samt ulike stønadsordninger knyttet til endringer i livssituasjon for barnefamilier (Nordisk ministerråd 2012).

Barneombudet (2016) har fremhevet at barn i Norge blir diskriminert med tanke på å få sine grunnleggende rettigheter oppfylt, herunder gjennom mangelfull spesialundervisning og svakt rettsvern mot mobbing, samt at barn har svak mulighet til å påpeke og få forbedret bistanden fra barneverntjenesten. I 2016 vokste 10,3 prosent av barna opp i husholdninger med vedvarende lavinntekt (Barne-, ungdoms- og familiedirektoratet 2018A), 5 prosent fikk behandling i psykisk helsevern i 2015 (Barne-, ungdoms- og familiedirektoratet 2018C), og 8 prosent av barn i grunnskolen fikk spesialundervisning (SSB 2017B). Samtidig viser barnevernstatistikken at 21 prosent av ungdommer har vært utsatt for fysisk vold fra foreldre i oppveksten (Barne-, ungdoms- og familiedirektoratet 2018D). Fire prosent av barnebefolkningen mottok hjelp fra barnevernet (Barne-, ungdoms- og familiedirektoratet 2018B), og i tillegg vil alle mindreårige asylsøkere som får innvilget opphold være under barnevernets ansvar, jfr. barnevernloven § 3-4. Barn med funksjonsnedsettelser kan også ha ulike behov for bistand fra det offentlige. Mer enn 1 av 5 norske kvinner og 1 av 10 menn har videre vært utsatt for former for seksuelle overgrep i sin barndom (Barne-, ungdoms- og familiedirektoratet 2018E). Samlet viser dette at en ikke ubetydelig andel barn vokser opp med ulike og også sammensatte utfordringer, som krever innsats fra flere ulike instanser. I en studie fra 2008 fremgår det dessuten at 65 prosent av barn og unge som hadde vært under barnevernets tiltak i en femtenårsperiode hadde mottatt sosialhjelp, og at over halvparten av disse var sosialhjelpsmottakere over lengre tid. I sammenligningsutvalget (som ikke hadde 
vært registrert under barnevernet), hadde 15 prosent mottatt sosialhjelp (Kristofersen og Clausen 2008, s. 20 og 46).

Innvandrerbarn representerte i 2015 over halvparten av barn som vokste opp i lavinntektsfamilier, mens de i år 2000 utgjorde 4 prosent (Epland og Kirkeberg 2017). I en undersøkelse av Kane, Neverdal og Stenberg (2018) fremholder Nav-veiledere at en del foreldre må søke om økonomisk sosialhjelp for å kunne la barna delta i aktiviteter i regi av skolen, og at de over lengre tid har måttet bortprioritere barnas fritidsaktiviteter til fordel for bolig og mat.

Wendelborg (2017) viser til at 6,6 prosent av elever opplever mobbing, og at dette også er en liten $\varnothing \mathrm{kning}$ fra året før. Dette skjer til tross for omfattende innsats både nasjonalt og lokalt, og analyser viser at programmer mot mobbing virker (Kunnskapsdepartementet 2013). I tillegg har man i Norge har lagt ned betydelig innsats mot mobbing siden systematisert kunnskap og de første programmene mot mobbing kom på 80-tallet (Olweus og Breivik 2017). Når det gjelder psykiske helseplager hos barn og unge, viser Ungdata-undersøkelsen for 2018 at forekomsten av selvrapporterte depressive symptomer har $\varnothing \mathrm{kt}$ hos både jenter og gutter, mens andelen som rapporterer å oppleve ensomhet, er «den høyeste som noen gang er registrert i Ungdata (Bakken 2018, s. 81).

Barn og unge opplever altså utfordringer på mange områder, og statistikken viser en økende tendens. Tallene i seg selv illustrerer at for å sikre barns rett til en trygg oppvekst og utvikling må den forebyggende innsatsen $\emptyset$ kes. Staten har iverksatt ulike universelle og selektive tiltak knyttet til barns og unges oppvekstvilkår, med mål om å utjevne ulikhet og å bremse negativ utvikling. Slike tiltak omfatter ulike målgrupper og innsatsområder, blant annet tiltak for barn i lavinntektsfamilier og tiltak tilknyttet barns fritids- og sosialiseringsarenaer (Becher, Bjerke, Martinsen og Øvrevik 2016, Bache-Hansen 2002). I tillegg har regjeringen Solberg utformet en strategi for $\varnothing k t$ satsing på barnefattigdom (Barne- og likestillingsdepartementet 2015). I rundskriv Q-16/2013 (Barne-, likestillings- og inkluderingsdepartementet, Kommunal- og regionaldepartementet, Arbeidsdepartementet, Helse- og omsorgsdepartementet, Justis- og beredskapsdepartementet og Kunnskapsdepartementet 2013, s. 1) poengteres det at «[g]odt forebyggende arbeid fokuserer ikke først og fremst på symptomer, men er generelt orientert med sikte på å fremme sunne barn og unge som håndterer framtidige utfordringer og risikoer». Her illustreres nettopp viktigheten av at forebygging handler om å unngå at problemer i det hele tatt oppstår, for barn som gruppe. 
Barneverntjenesten er en av flere instanser i samfunnets kollektive ansvar for trygging av barns oppvekstvilkår. Nåværende lovgivning pålegger barneverntjenesten, gjennom sitt universelle forebyggingsansvar, å identifisere og adressere områder hvor innsats i lokalsamfunnet er nødvendig for å motvirke en ytterligere $\varnothing$ kning av oppvekstproblematikk. Når statistikk viser at barns opplevelser av oppvekstforhold går i negativ retning, bør forebyggingsansvaret for alle hjelpeinstanser, inkludert barneverntjenesten, heller økes enn reduseres. Forslaget om å innskrenke barneverntjenestens universelle forebyggingsansvar i en slik kontekst synes derfor å være et steg i feil retning med risiko for svekkelse av barnets rett til en trygg oppvekst og utvikling.

\section{Barns rett til beskyttelse mot omsorgssvikt fordrer kompetanse i å identifisere og adressere risiko}

Barnevernslovutvalget foreslår at barneverntjenestens ansvar for å sikre barnets omsorg og beskyttelse skal avgrenses til når barnets «omsorgssituasjon» tilsier det eller barnet «utsetter sin helse eller utvikling for fare». Utvalget legger til grunn for en slik presisering at dette kan tydeliggjøre ansvarsfordelingen mellom barneverntjenesten og andre instanser, og at det igjen kan «redusere forventningen om at barnevernet har ansvar for alle barn som trenger hjelp eller bistand på en eller annen måte» (NOU 2016: 16, s. 93).

Barnevernslovutvalget har som tidligere nevnt også problematisert at barneverntjenesten bruker ressurser på saker hvor saksforholdet hører inn under andre instansers ansvarsområder. Barnevoldsutvalget (NOU 2017: 12, s. 91) viser til «mye god vilje hos myndighetene» angående innsats mot vold og overgrep mot barn. Samtidig påpekes det en manglende kommunikasjon og samordning mellom de ulike tjenester. Utvalget fremhever også at det går med mye tid til rapportering på tiltak som går over i hverandre, samt at «mange av tiltakene er små og ikke innehar et systemperspektiv» (ibid, s. 91). At flere kommunale instanser forvalter bistandsformer som er relativt like, kan $\varnothing$ ke risikoen for at barn og familier med mer udefinerte behov ikke vet hvor de skal henvende seg, og dermed blir en kasteball mellom flere instanser før de får hjelp. På den annen side vil eksempelvis kommunale helse- og omsorgstjenester, økonomisk bistand fra Nav samt ulike pedagogiske tjenester kunne oppleves mindre belastende og inngripende å oppsøke og ta imot enn barneverntjenester (Kane, 2016). Øvrige instansers innsats er derfor også viktig som ledd i kommunens samlede tjenestetilbud rettet mot barns oppvekst. 
En innsnevring av barneverntjenestens forebyggingsansvar fordrer at $\varnothing v$ vrige hjelpeinstanser har, eller raskt opparbeider seg, nødvendig kompetanse i å identifisere risiko hos barn. Når ansatte i skole og barnehage er bekymret for et barns omsorgssituasjon, viser forskning at de ansatte nøler med å inngi melding til barneverntjenesten fordi de er usikre på grensene mellom taushetsplikt, opplysningsrett og opplysningsplikt (NOU 2017: 12, s. 136). En undersøkelse blant barnehageansatte viser at de etterlyser mer samarbeid med barneverntjenesten for å øke sin kompetanse både til å vurdere hvorvidt bekymringsverdige forhold innebærer en risiko for et barn, og til å beslutte hvorvidt bekymringen skal føre til en melding til barneverntjenesten (Kane, Neverdal og Myrvang 2018). For å sikre barnets rett til beskyttelse mot omsorgssvikt er det nødvendig at barneverntjenesten aktivt og systematisk tar ansvar for å medvirke til at ansatte i barnehager, skoler, helsetjenester og Nav oppnår og opprettholder kompetanse om barn i risiko. Slik kompetanseoverføring må sees som en nødvendig del av barneverntjenestens universelle forebyggingsansvar for å sikre barnets rett til beskyttelse mot omsorgssvikt.

\section{Barnets rett til å bli hørt fordrer kompetanse i å ta barnets perspektiv}

Barnevernlovsutvalget foreslår å innføre en egen bestemmelse om barneverntjenestens plikt til å samarbeide med barn og foreldre (NOU 2016: 16, s. 64) og fremhever betydningen av slikt samarbeid i en tidlig fase for å finne mest hensiktsmessig tiltak. Etter Barnekonvensjonens artikkel 12 gjelder barnets rett til å bli hørt «alle forhold som vedrører barnet», og deres mening skal vektlegges i samsvar med deres alder og modenhet. Dette innebærer at barnets rett å bli hørt gjelder handlinger og beslutninger på alle livsområder, og ikke er knyttet til konkrete saksforhold som eksempelvis en barnevernsak.

For at barnets rett til å bli hørt skal være en reell rettighet, må barnet få nødvendig informasjon som kan danne grunnlag for dets meningsdannelse og medvirkning. Rettigheten gjelder overfor alle forvaltningsorganer. I regjeringens gjennomgang av alvorlige volds- og overgrepssaker mot barn (NOU 2017: 12, s. 11) problematiseres det at det har vært en «fremtredende svikt» at de involverte instansene «unnlot å snakke med barna selv». Også undersøkelsen av Kane et al. (2018) viser at ingen av de spurte Nav-ansatte snakker med barna når foreldre søker om økonomisk bistand til barnas skole- og fritidsrelaterte utgifter. 
Unnlatelse av å snakke med barn direkte gir forvaltningsorganer et mindre tilfang av barns egne opplevelser av sine oppvekstforhold, både på godt og vondt.

Barnevoldsutvalgets utredning fremholder behovet for mere informasjon til barn og unge om «hvem barneverntjenesten er, og hva de kan hjelpe til med». Dette begrunnes med at barn som selv har vært utsatt for omsorgssvikt, «lærte hjemme at barneverntjenesten var noe de burde være redd for, noen som tok barna fra forelderen sine» (NOU 2017: 12, s. 85). Ifølge Grimen (2009) kan en legge til grunn at tillit utvikles gjennom samhandling, og at tillit også vil «lette overføring av informasjon og kunnskap» (ibid, s. 74). Barneverntjenestens informasjonsvirksomhet overfor barn og unge kan øke deres kunnskap om hvor de kan få hjelp til sine utfordringer, og kan på den måten innebære en slik tillitsbygging. Dette illustrerer behovet for at barneverntjenesten er synlig gjennom generelt informasjonsarbeid rettet mot barn og unge i både barnehage, skole og fritidsarenaer.

FNs barnekomité fremhever i sin generelle kommentar nr. 12 (2009) betydningen av at barn blir hørt både som individ og som gruppe. En slik gruppe kan eksempelvis være en skoleklasse, en interessegruppe eller barn i et bestemt lokalsamfunn. Vi fremhever derfor nødvendigheten av at barneverntjenesten som en del av det universelt forebyggende arbeid fortsatt er synlig på barns ulike oppvekstarenaer for å oppnå kontakt og dialog med barn og unge i lokalsamfunnet generelt og for å informere om barneverntjenestens ansvarsområder spesielt.

Avgrensning og oppdeling av arbeidsoppgaver innenfor velferdstjenester kan føre til at sosialarbeideren mister kontakt med «brukernes sosiale vilkår», og at konsekvensene av dette igjen kan bli en «redusert forståelse for brukerens sammensatte livssituasjon» (Kroken og Madsen 2016, s. 15). Å se et barns hjelpebehov og å tilrettelegge for dets medvirkning fordrer kompetanse til å ta inn over seg barnets konkrete situasjon og dets egne opplevelser. En slik evne til innlevelse kan omtales som mentaliseringsevne (jfr. Kvello 2015, s. 48), det vil si å kunne oppfatte og ta inn over seg den andres perspektiver og å kunne holde flere perspektiver oppe samtidig. Ett av disse perspektiver er ens eget, for en må også forstå hvordan ens egen forståelse og reaksjon påvirker den andres opplevelse. Forfatteren forklarer videre at mentalisering «binder sammen mye av det som er kjernen i omsorg for barn og danner grunnlaget for gode relasjoner - uansett personers alder». Skårderud og Sommerfeldt (2013, s. 60) uttrykker at «[m]entalisering av den andre vil også føre med seg empatisering av den andre». Barnets behov og den voksnes empati og mentaliseringsevne er derfor sentrale faktorer i forståelsen av barn og oppvekst. Slik relasjonsforståelse er en sentral del i 
sosialfaglige utdanninger og er derfor en viktig del av barneverntjenestens særegne kompetanse. Tilfanget av kunnskap fra barn og deres familier vil være en ressurs som barneverntjenesten får gjennom sitt selektive og indiserte forebyggingsarbeid, noe som kan sees som et nødvendig bidrag til kommunens totale universelle forebyggingsinnsats.

Oppsummert vil vi fremheve at barneverntjenesten har en særlig kompetanse til å ta barns perspektiv. Vi vil derfor argumentere for viktigheten av at barneverntjenesten fortsatt beholder sitt ansvar for å oppsøke arenaer hvor barn som gruppe kan informeres, gi uttrykk for sine meninger og bli hørt. Vi hevder at så lenge ikke alle hjelpeinstanser for barn og familier systematisk praktiserer samtaler med barn om forhold som angår dem, vil barnets rett til å bli hørt svekkes dersom barneverntjenestens forebyggingsansvar overfor alle barn i kommunen blir redusert.

\section{Synergi mellom barneverntjeneste og lokalsamfunn gir kortreist handlekraft}

Barneverntjenesten opparbeider seg kunnskaper, oversikt og erfaringer om årsaker og virkninger av barns og familiers ulike problemområder gjennom sine kjerneoppgaver knyttet til meldinger, undersøkelser, råd/veiledning, iverksettelse av samtykkebaserte hjelpetiltak og forberedelser av tvangsvedtak. For eksempel kan barneverntjenesten få kunnskap om mobbeproblematikk og individuelle konsekvenser av dette fra både de barna som er blitt utpekt som henholdsvis mobber(e) og/eller mobbeoffer, og fra deres foreldre. Dersom mobbingen foregår på fritidsarenaer, eventuelt ved bruk av digitale medier, er det ikke nødvendigvis klart hvor ansvaret for ivaretakelse av de involverte barna ligger. Barneverntjenesten er også den instans som gjennom sitt arbeid kan se sammenhengen mellom barns situasjon i førskole, grunnskole og videregående skole fordi de i noen saker følger barns situasjon over mange år. I andre saker kan instansen arbeide med søsken som er i ulike aldersgrupper. Det kan også være uklart hvem som har ansvar for at ikke situasjonen skal forverre seg og flere barn skal bli involvert i samme eller lignende mobbesituasjoner.

Med sitt ansvar for barns oppvekstvilkår, gjennom forebygging og tiltaksarbeid, er barneverntjenesten den instansen som til enhver tid kan forventes å inneha en særlig dybdekunnskap om lokale forhold som hemmer og fremmer barns og familiers levekår. I tillegg vil deres kunnskap og erfaring dekke hele barndommen, hvor barnehagens og skolens kunnskap er begrenset til et mindre aldersspenn. Barneverntjenestens utveksling av sin samlede kunnskap med øvrige instanser i lokalsamfunnet som arbeider med og for barn, kan 
derfor sikre at også disse instansene kan initiere mer treffsikre universelle og selektive forebyggingstiltak med mål om å forhindre barneverntiltak for barnet. Å overføre barneverntjenestens universelle forebyggingsansvar til kommunens ordinære virksomhet vil kunne føre til at lokalkunnskap om oppvekstforhold for barn og unge, ofte med både sammensatte og vedvarende utfordringer, kan gå tapt. Det kan også føre til at barn utsettes for unødige lidelser fordi det tar for lang tid å sette i verk adekvate tiltak.

En avgrensning av barneverntjenestens forebyggingsansvar kan på kort sikt trolig gi bedre jobbtilfredshet for ledere, da de lettere kan identifisere konkret resultatoppnåelse (Kroken og Madsen 2016). Samtidig påpeker forfatterne at en slik avgrensning, hvor fagfolk mister faglig og etisk handlingsrom til å agere i tide på bekymringsfulle forhold, på sikt vil kunne gi en opplevelse av avmakt og ansvarsfraskrivelse. Ut fra dette ser vi risikoen for at barnevernsarbeidere får et snevrere handlingsrom for forebygging i lokalsamfunnet.

Forebygging fordrer kunnskaper om sammenhengen mellom oppvekstvilkår, risiko og beskyttelse. Et hovedområde for sosialfaglige utdanninger er å fremme befolkningens muligheter til å mestre sine liv og å forebygge sosiale problemer, og innenfor barnevernpedagogutdanningen er hovedfokuset sosialpedagogisk arbeid med barn og unge (Utdannings- og forskningsdepartementet 2005 A og B). Sosialpedagogikkens rolle er, ifølge Cederlund og Berglund (2017, s. 19) «at förstärka och bidra till långsiktiga förändringsprocesser genom vardagliga männskliga möten, lystnande och samarbete och därmed skapa de bästa förutsätningarna för att kunna handtera problem och svårigheter». Sentrale temaer innen sosialpedagogikken er barns mulighet for inkludering og forståelsen av de sammenhenger samfunnsutviklingen skaper i barn og familiers livsvilkår (Gjertsen 2010, s. 5), samt «den sosiale tilhørigheten til og deltakelsen i fellesskapet» (Mathiesen 2008, s. 16). I sum handler det sosialpedagogiske perspektivet om barns inkludering i sine lokalsamfunn og å identifisere og avhjelpe risikofaktorer i oppvekstmiljøet, og dette perspektivet representerer et sentralt bidrag i å sikre barnets menneskerettslige krav på forsvarlige oppvekstvilkår. I 2014 representerte barnevernpedagoger 47 prosent og sosionomer 29 prosent av ansatte i barneverntjenester i norske kommuner (NOU 2016:_16, s. 62). Med så høy representasjon av sosialfaglig, herunder sosialpedagogisk kompetanse, er den kommunale barneverntjenesten den instans som må sies å ha den mest samlede og spissede kompetanse om hvilke forhold som fremmer og hemmer barns oppvekst i sitt lokalsamfunn. Imidlertid er det en kjensgjerning at det er behov for revidering og styrking av dagens sosialfaglige utdanninger, 
samtidig som det er fremmet forslag om krav om masterkompetanse for å arbeide i kommunal barneverntjeneste (NOU 2009: 8, Kvaran 2015, Neverdal og Halvorsen 2016). Dette illustrerer også et $\varnothing \mathrm{kt}$ fokus på blant annet sosialpedagogisk kompetanse i barnevernfeltet. Et bortfall av barneverntjenestens universelle forebyggingsansvar fordrer at andre instanser og fagpersoner som arbeider med og for barn, får spisset sin sosialpedagogiske kompetanse. Det vil imidlertid ta tid før andre utdanninger som eksempelvis barnehagelærere, lærere og helsesøstre får formalisert og oppfylt dette økte kompetansebehovet.

På bakgrunn av våre drøftinger av barneverntjenestens særlige mandat og kompetanse vurderer vi at ved å la barneverntjenesten beholde, og også videreutvikle, sitt universelle forebyggingsansvar vil instansen kunne arbeide mer målrettet for å bedre forholdene for alle barn i kommunen. Dette vil igjen kunne redusere antall og grad av barneverntiltak rettet mot enkeltbarn, med det stigma et slikt offentlig inngrep medfører. Vi påpeker også at forebyggingsarbeid, uavhengig av hvilken instans som er pålagt ansvaret, er et vanskelig område. Til tross for at det finnes kunnskap om årsaker og virkninger av problematikk som eksempelvis mobbing, rus og fattigdom, samt at ulike forebyggingsprogrammer har vært satt i verk, viser ulike medieoppslag og rapporter at de ulike problemer ikke er eliminert. Fløtten og Grødem (2014) påpeker at vi i Norden ikke har noen fullgod evaluering av hvilke tiltak for barn som vokser opp i fattigdom som har god effekt. Dette tyder på at fullgod evaluering av forebygging og hvilke tiltak som har effekt, er et komplekst område.

Kroken og Madsen (2016, s. 18) reiser spørsmål ved om oppdeling og avgrensning av sosialarbeiderens handlingsrom også fører til devaluering av nærhet, «moralsk ansvar og dømmekraft som blir utøvd i lokale kontekster». Integrering av kompetanse om barns oppvekstvilkår i lokalsamfunnet krever samhandlingsarenaer og samarbeid hvor alle de deltakende instansene oppfatter at de har både nytteverdi og ansvar. Samarbeid uten ansvar kan lett bli salderingspost og gi grobunn for manglende involvering. Dette vil igjen medføre risiko for at fagpersoners drivkraft gjennom empati, mentalisering og nærhet til barns egne opplevelser blir redusert i de viktige prioriteringene som må til for å sikre flest mulig barn en god nok oppvekst.

Et viktig prinsipp i all offentlig innsats er at den skal være nærmest mulig de(n) som har behov (jfr. Helsedirektoratet 2017, s. 10), og hjelpen må derfor finnes nært barnet og i barnets oppvekstmiljø. Et annet viktig moment er at forebygging ut fra et lokalt kunnskapsgrunnlag til 
enhver tid vil være mere treffsikkert i forhold til utfordringer innenfor det enkelte lokalsamfunn.

Oppsummert fremhever vi betydningen av slik kortreist handlekraft, og at barneverntjenestens involvering i det universelle forebyggingsansvar kan gi en synergieffekt i sikringen av barns rett til trygge oppvekstvilkår. I tillegg fremholder vi at å først fjerne barneverntjenestens universelle forebyggingsansvar og samtidig overføre dette til kommunens generelle ansvar vil være en risikabel strategi som kan føre til en svekkelse av barnets rettigheter etter barnekonvensjonen, og også barnevernlovens formålsbestemmelse om at barn skal ha nødvendig hjelp til rett tid.

\section{Avsluttende betraktninger}

Med utgangspunkt i barnevernslovutvalgets forslag om å innskrenke barneverntjenestens forebyggingsansvar rettet mot alle barn i kommunen, har vi drøftet hvilken betydning denne instansens universelle forebyggingsansvar kan ha for sikring av det enkelte barns menneskerettslige krav på en trygg oppvekst og utvikling, beskyttelse mot omsorgssvikt og til å bli hørt i saker som angår det.

Vi har innledningsvis synliggjort at mange barn i Norge har behov for offentlig innsats i form av både forebygging og særlige tiltak, og at antall barn med ulike utfordringer $\emptyset$ ker. Vi har derfor fremhevet at før man kan vise til evalueringer og statistikk som viser markante forbedringer i barns oppvekstforhold, vil en reduksjon av barneverntjenestens forebyggingsansvar innebære en risiko for at barnets rettigheter etter barnekonvensjonen blir svekket. En slik svekkelse vil å så fall representere et brudd på barnevernlovens formålsbestemmelse.

Barnevernslovutvalgets forslag om at det fortsatt skal være et kommunalt ansvar å tilrettelegge for et trygt oppvekstmiljø for alle barn, ser vi som et viktig bidrag for å forstå sammenhengen mellom lokalsamfunnet og barnets oppvekstvilkår. Likevel ser vi en risiko for at kommunens kollektive forebygging kan bli mindre treffsikker uten barneverntjenestens ansvar og deltakelse. Universelt forebyggende innsats er ikke bare mindre ressurskrevende enn barneverntjenestens intervensjon og saksbehandling vedrørende tiltak overfor enkeltbarn, men også mindre stigmatiserende og inngripende i barnas privat- og familieliv. 
Barnevernslovutvalgets forslag om at kommunen «skal vurdere hvordan barneverntjenestens særlige kompetanse kan integreres i kommunens universelle forebygging», er også et viktig bidrag for å trygge barns oppvekstmiljø. Imidlertid anser vi forslaget som en forholdsvis åpen føring om samarbeid heller enn en forpliktelse. For å sikre barnets rett til å bli hørt i saker som angår det, har vi fremhevet viktigheten av at barns erfaringer blir etterspurt og innhentet på både gruppe- og individnivå. Barneverntjenesten har, gjennom systematisk å snakke med barn som del av sin arbeidsmåte, en særlig kompetanse når det gjelder å ta barnets perspektiv. Barneverntjenesten er også trolig den instansen som oftest er i direktekontakt med de kanskje mest sårbare barn i vårt samfunn. Ut fra deres kunnskaper om barn som individer og som gruppe i den enkelte kommune bør barneverntjenesten derfor fortsatt ha en sentral rolle i å bidra til at barns erfaringer kan bli analysert og omsatt til universelle forebyggingstiltak i lokalsamfunnet.

En lovendring som innskrenker barneverntjenestens universelle forebyggingsansvar, vil på kort sikt kunne frigjøre mer tid til barneverntjenestens arbeid med barn som har særlig behov for hjelpe- og omsorgstiltak. Dette avhenger imidlertid av hvor mye tid barneverntjenesten faktisk brukte på slik universell forebygging før lovendringen. Dessuten vil det kreve tid å inkorporere barneverntjenestens kunnskaper i nye samarbeidsformer og plandokumenter. I tillegg vil fremtidig forskning kunne påvise hvorvidt innskrenkningen i forebyggingsansvaret faktisk medfører at antallet barn med barneverntiltak øker, reduseres, eller forblir uendret, og hvorvidt flere barn får rett hjelp til rett tid, jfr. barnevernlovens formålsbestemmelse $§ 1-1$.

Medieoppslag om enkeltsaker med alvorlig utgang kan gi allmenheten kunnskaper om hvor mye overlast barn kan lide til tross for at flere offentlige hjelpeinstanser er involvert. Slike saker synliggjør også hvordan barn kan falle mellom flere stoler når instanser med kunnskaper om et barns situasjon og med ansvar å bistå, ikke agerer korrekt og i tide. Medieoppslag kan også vise frem at universelle forebyggende tiltak kan ha stor effekt i lokalsamfunn med alvorlige problemer blant ungdom, som for eksempel i bydel Alna i Oslo kommune (Unosen 2018) og i Reykjavik på Island (Hjelp til Hjelp 2017). Dersom universell forebygging opphører å være en del av barneverntjenestens lovpålagte oppgaver, vil instansens ressurser til slikt arbeid sannsynligvis bli redusert eller endog bortfalle. Vi fremholder at forebyggingsansvar for barn må forbli hos barneverntjenesten, med sine fagpersoner som er i direkte kontakt med barn, og som kan ta inn over seg barnets perspektiver og behov. Barnet er gitt grunnleggende rettigheter gjennom barnekonvensjonen. Likevel er barnet som rettssubjekt en svak part, både i forhold til foreldre og til offentlige instanser. Ut fra målet om at alle barn 
skal ha trygge oppvekstvilkår, argumenterer vi for at barneverntjenestens ansvar og rolle i det kommunale forebyggingsarbeidet er en nødvendig brikke i myndighetenes ansvar for å sikre hvert enkelt barn dets grunnleggende menneskerettigheter.

\section{Litteratur}

Backe-Hansen, E. (2002). Fattige barn i Norge: Tilstandsbilder og tiltak. NOVA Rapport 2002.

Bakken, A. (2018). Ungdata. Nasjonale resultater 2018. NOVA Rapport 8/2018. Oslo: NOVA.

Barneombudet. (2016, 17. november). Barn diskrimineres - Også i Norge. Hentet fra https://barneombudsbloggen.wordpress.com/2016/11/17/barn-diskrimineres-ogsa-i-norge/.

Barne- og familiedepartementet. (1992). Ot.prp. nr. 44. Om lov om barneverntjenester (barnevernloven). Oslo: Departementenes servicesenter. Informasjonstjeneste.

Barne-, likestillings- og inkluderingsdepartement, Kommunal- og regionaldepartementet, Arbeidsdepartementet, Helse- og omsorgsdepartementet, Justis- og beredskapsdepartementet, Kunnskapsdepartementet. (2013). Forebyggende innsats for barn og unge. (Rundskriv Q16/2013).

Barne- og likestillingsdepartementet. (2015). Barn som lever i fattigdom. Regjeringens strategi mot barnefattigdom 2015-2017.

Barne-, ungdoms- og familiedirektoratet. (2018A). Barnevernsstatistikk. Hentet fra https://www.bufdir.no/Statistikk_og_analyse/Barnefattigdom/.

Barne-, ungdoms- og familiedirektoratet. (2018B). Barnevernsstatistikk. Hentet fra https://www.bufdir.no/Statistikk_og_analyse/Barnevern/.

Barne-, ungdoms- og familiedirektoratet. (2018C). Psykisk helse.

Hentet fra https://www.bufdir.no/Statistikk_og_analyse/Oppvekst/Helse/Psykisk_helse/.

Barne-, ungdoms- og familiedirektoratet. (2018D). Vold og overgrep mot barn. Hentet fra https://www.bufdir.no/Statistikk_og_analyse/Oppvekst/Vold_og_overgrep_mot_barn/Barn_ut satt_for_vold_i_familien/.

Barne-, ungdoms- og familiedirektoratet. (2018E). Seksuelle overgrep mot barn. Hentet fra https://www.bufdir.no/Statistikk_og_analyse/Oppvekst/Vold_og_overgrep_mot_barn/Seksuel le_overgrep_mot_barn/.

Becher, R., Bjerke, M., Martinsen, F. og Øvrevik, J. Inneklima i skoler og barnehager. Helsemessig betydning for barn og unge, Folkehelseinstituttet. Rapport Oktober 2016. Hentet fra https://fhi.no/publ/2016/inneklima-i-skoler-og-barnehager/. 
Bendiksen, L.R.L. og Haugli, T. (2018). Sentrale emner i barneretten. 3. utg. Oslo: Universitetsforlaget.

Cederlund, C. og Berglund, S.A. (2017). Socialpedagogik - pedagogiskt socialt arbete. 2. utg. Stockholm: Liber AB.

Epland, J. og Kirkeberg, M.I. (2017). Barn i lavinntektshusholdninger. Ett av ti barn tilhфrer en husholdning med vedvarende lavinntekt. Statistisk Sentralbyrå 2017. Hentet fra https://www.ssb.no/inntekt-og-forbruk/artikler-og-publikasjoner/ett-av-ti-barn-tilhorer-enhusholdning-med-vedvarende-lavinntekt.

Fløtten, T. og Grødem, A.S. (2014). Helhetlige tiltak mot barnefattigdom. Fafo-rapport 201418.

FNs barnekomité. (2003). Generell kommentar nr. 5. Generelle tiltak til gjennomføring av Konvensjonen om barnets rettigheter.

FNs barnekomité. (2009). Generell kommentar nr. 12. Barnets rett til å bli hørt.

FNs barnekomité. (2013). Generell kommentar nr. 14. Barnets rett til at hans eller hennes beste skal vare et grunnleggende hensyn.

FNs konvensjon om barnets rettigheter (1989).

Gjertsen, P-Å. (2010). Sosialpedagogikk. Forståelse, handling og refleksjon. 2. utgave Bergen: Fagbokforlaget.

Grimen, H. (2009). Hva er tillit? Oslo: Universitetsforlaget.

Gulliksen, J. (2010, 4. oktober). Jeg tenker nok du skjønner det sjøl. NRK Vestfold. Hentet fra https://www.nrk.no/vestfold/christoffers-mormor-bidrar-i-bok-1.7320173.

Helsedirektoratet. (2017). Veileder om rehabilitering, habilitering, individuell plan og koordinator. Hentet fra

https://helsedirektoratet.no/Retningslinjer/Rehabilitering,\%20habilitering,\%20individuell\%20 plan\%20og\%20koordinator.pdf.

Hennum, R. (2106). Retten til beskyttelse mot vold, overgrep og utnyttelse. Høstmælingen, N., Kjørholt, E.S. og Sandberg, K. (2016). Barnekonvensjonen - Barns rettigheter i Norge. 2. utg. Oslo: Universitetsforlaget.

Hjelp til hjelp. Nettportal for psykisk helse. (2017, 17. november). Disse 5 grepene fikk ungdom på Island bort fra alkohol og narkotika. Hentet fra https://www.hjelptilhjelp.no/Rusproblemer/fem-mater-island-fikk-ungdommen-bort-fraalkohol-og-narkotika

Kane, A.A. (2016). Barnets menneskerettslige krav på beskyttelse - en sammenligning av juridiske rammer for bekymringsmelding og unders $\varnothing$ kelse i Norge og England. Tidsskriftet Norges Barnevern 01/2016, s. 52-67. Oslo: Universitetsforlaget. DOI: 10.18261/issn.18911838-2016-01-05.

Kane, A.A., Neverdal, S. og Myrvang, R. (2018). Barneverntjenestens medansvar for barnehagebarns rett til beskyttelse mot omsorgssvikt. I Schõnfelder, W., Andersen, S.T. og 
Kane, A.A. Handlingsrom i barnevernet - Muligheter og begrensninger for profesjonsutøveren. Bergen: Fagbokforlaget.

Kane, A.A., Neverdal, S. og Stenberg, O. (2018). Barnets rett til forsvarlig levestandard Utøvelse av skjønn i NAV og barneverntjeneste. Fontene Forskning 2018/1. Oslo:

Fellesorganisasjonen (FO).

Kristofersen, L.B og Clausen, S.E (2008). Barnevernsklienter i Norge 1990-2005. En longitudinell studie. Norsk institutt for forskning om oppvekst, velferd og aldring. NOVArapport nr. 3/2008.

Kroken, R. og Madsen, O.J. (red) (2016). Forvaltning av makt og moral i velferdsstaten. Fra sosialt arbeid til «arbeid med deg selv»? Oslo: Universitetsforlaget.

Kunnskapsdepartementet. (2013). Effektivt mot mobbing. Hentet fra https://www.regjeringen.no/no/dokument/dep/kd/rapporter_planer/aktuelle-analyser/aktuelleanalyser-om-andre-tema/effektivt-mot-mobbing1/id592744

Kvaran, I. (2015). Femårig utdanning som krav til arbeid i barnevernet. Fontene 2015/8. Oslo: Fellesorganisasjonen (FO).

Kvello, Ø. (2015). Barn i Risiko. Skadelige omsorgssituasjoner. Oslo: Gyldendal Akademisk.

Mathiesen, R. (2008). Sosialpedagogisk perspektiv - på individ og fellesskap. Oslo:

Universitetsforlaget.

Neverdal, S. og Halvorsen, T. (2016). Barnevern, kompetanse og utdanning. Fontene forskning 2016/2. Oslo: Fellesorganisasjonen (FO).

Nordisk ministerråd (2012). Velferdsstaten i et nordisk perspektiv. Norsk formannskapsprogram i Nordisk ministerråd. Hentet fra

https://www.regjeringen.no/globalassets/upload/fad/kampanje/norden2012/nmr_formannskap sprogrammet.pdf.

NOU 2009: 8 (2009). Kompetanseutvikling i barnevernet Kvalifisering til arbeid $i$ barnevernet gjennom praksisnar og forskningsbasert utdanning. Oslo: Departementenes servicesenter, Informasjonsforvaltning.

NOU 2016: 16 (2016). Ny barnevernslov. Sikring av barns rett til omsorg og beskyttelse. Oslo: Departementenes servicesenter, Informasjonsforvaltning.

NOU 2017: 12 (2017). Svikt og svik. Gjennomgang av saker hvor barn har vart utsatt for vold, seksuelle overgrep og omsorgssvikt. Departementenes servicesenter, Informasjonsforvaltning.

NRK (2018, 15. mai). Dom i Valdres-saken kommer i dag. Hentet fra https://www.nrk.no/nyheter/valdres-saken-1.13485157.

Olweus, D. og Breivik, K. (2017). Mobbing i skolen - grunnleggende fakta og tiltak med Olweusprogrammet. I Klepp K.I. og Aarø, L.E. (red.), Ungdom, livsstil og helsefremmende arbeid. 4. utg. Oslo: Gyldendal Akademisk. 
Oppedal, M. (2008). Fattige barns rett til økonomisk hjelp. I Harsløf. I. og Seim, S. (red), Fattigdommens dynamikk - Perspektiver på marginalisering i det norske samfunnet. Oslo: Universitetsforlaget.

Rees, G. og Main, G. (red.) (2015). Children's views on their lives and well-being in 15 countries: An initial report on the Children's Worlds survey, 2013-14. York, UK: Children's Worlds Project (ISCWeB).

Sandberg, K. (2014). Barnekonvensjonens vern mot sammensatt diskriminering. I Hellum, A. og J. K-Olsen (2014) (red.), Like rettigheter - ulike liv. Rettslig kompleksitet i kvinne-, barneog innvandrerperspektiv. Oslo: Gyldendal Juridisk.

Sandberg, K. (2016). Barnets rett til å bli hørt. I Høstmælingen, N., Kjørholt, E.S. og Sandberg, K. (2016), Barnekonvensjonen - Barns rettigheter i Norge. 2. utg. Oslo: Universitetsforlaget.

Setten, K. (2018, 7. februar). Tilsynsrapport: Jente (16) som knivdrepte hadde ikke fått forsvarlig behandling. Dagbladet. Hentet fra https://www.dagbladet.no/nyheter/tilsynsrapport-jente-16-som-knivdrepte-hadde-ikke-fattforsvarlig- behandling/69427116.

Sigurdsen, R. (2015). Rett til barneverntjenester. Tidsskrift for familierett, arverett og barnevernrettslige spфrsmål. Nr. 4/2015. Oslo: Universitetsforlaget.

Skoghøy, J.E.A. (2016). «Hvilken betydning har uttalelser av FNs menneskerettskomité og FNs barnekomité som rettskilder? Foredrag på Nordisk høyesterettsdommerseminar i Oslo 14. - 15. mars 2016. https://www.domstol.no/globalassets/upload/hret/artikler-ogforedrag/betydningen-av-uttalelser-av-menneskeretts--og-barnekomiteen---foredrag.pdf (Lastet ned 20.8.18)

Skårderud, F. og Sommerfeldt, B. (2013). Miljøterapiboken. Mentalisering som holdning og handling (MBT-M) Oslo: Gyldendal Akademiske

SSB. Statistisk sentralbyrå (2017 A). Antall barn i Norge. Hentet fra http://www.ssb.no/a/barnogunge/2017/bef/.

SSB. Statistisk sentralbyrå (2017 B). Barnevern. https://www.ssb.no/barneverng/ (lastet ned 1. mars 2018)

Stang, E.G. og Sveaass, N. (2016). Hva skal vi med menneskerettigheter? Oslo: Gyldendal Akademisk.

Storø, J. (2017, 6. januar). Glassjenta-saken - et lærestykke! Aftenbladet. Hentet fra https://www.aftenbladet.no/meninger/debatt/i/7v9Jw/Glassjenta-saken--et-larestykke.

Unosen, H. (2018, 4. september). Marerittvinter ble drømmesommer. Dagsavisen. Hentet fra https://www.dagsavisen.no/oslo/marerittvinter-ble-drommesommer-1.1196743.

Utdannings- og forskningsdepartementet. (2005 A). Rammeplan og forskrift for 3-årig barnevernspedagogutdanning. Hentet fra https://www.regjeringen.no/globalassets/upload/kilde/kd/pla/2006/0002/ddd/pdfv/269385rammeplan_for_barnevernspedagogutdanning_05.pdf.

Utdannings- og forskningsdepartementet. (2005 B). Rammeplan for 3-årig sosionomutdanning. Hentet fra 
https://www.regjeringen.no/globalassets/upload/kilde/kd/pla/2006/0002/ddd/pdfv/269389rammeplan_for_sosionomutdanning_05.pdf.

Wendelborg, C. (2017). Mobbing og arbeidsro i skolen 2017 og 18. NTNU. Hentet fra https://www.udir.no/tall-og-forskning/finn-forskning/rapporter/elevundersokelsen-2017mobbing-og-arbeidsro2/. 